\title{
Performance Improvement through Interpersonal Communication and Job Satisfaction (Empirical Study of Nurses in Puskesmas/Community Health Center) in Makassar, Indonesia
}

\author{
Fauziah $^{1}$, Isnawati Osman ${ }^{2}$, Dian A.S. Parawansa ${ }^{3}$ and Jumidah Maming ${ }^{4}$ \\ ${ }^{1}$ Hasanuddin University, e-mail: fauziah@unhas.ac.id \\ ${ }^{2}$ Hasanuddin University, e-mail: Isna.osman@unhas.ac.id \\ ${ }^{3}$ Hasanuddin University, e-mail: dian.parawansa@unhas.ac.id \\ ${ }^{4}$ Hasanuddin University, e-mail: jumida@unhas.ac.id
}

\begin{abstract}
This study aimed to analyze the effect of interpersonal communication and the job satisfaction nurses' performance. The study was designated as a quantitative research. The research was conducted in the community health center (PUSKESMAS) in Makassar, Indonesia. The study applied structured questionnaires and employed multi-item scales. The sampling technique was determined by proportional random sampling. The data were analyzed using path analysis. The results showed that: (1) the interpersonal communication had a positive and significant effect on work satisfaction, (2) the interpersonal communication had a positive and significant effect on the performance, (3) the job satisfaction had a positive and significant impact on performance, (4) the interpersonal communication had a positive and significant indirect effect on performance through the job satisfaction of the nurses of Puskesmas in Makassar. These results revealed that all proposed hypotheses were accepted.
\end{abstract}

Keywords: interpersonal communication, job satisfaction, performance

\section{Introduction}

In order to provide health care services to the community, it is necessary to improve the quality of professional nursing services, namely health care services that provide services to the community according to standards (Sitorus, 2000). Data from the Makassar City Health Office (January 2017) there are 46 health centers and a total of 405 nursing staff in the city of Makassar. Based on the results of interviews with a number of people who took care in several health centers in Makassar stated that the provision of health care services was not optimal. Therefore, it is necessary to improve performance for nurses in providing services to the community.

Employee performance is an important aspect of the company. A strategic program is needed to improve productivity or employee performance in order to support the success of achieving the goals of the company. Performance is the result of work achieved by employees, both individually and in groups, according to the responsibilities given and in accordance with established standards both in quality and quantity (Mangkunegara, 2005). Gibson et al. (1997) explains that there is a reciprocal relationship between performance and job satisfaction. On the one hand, job satisfaction causes an increase in performance, and on the other hand, job satisfaction can also occur due to performance or work performance so that more productive workers will get satisfaction. Performance indirectly results in job satisfaction. Good performance is caused by the presence of both intrinsic and extrinsic rewards. If the employee feels that the award is received fairly, then the award will increase job satisfaction (Vecchio, 1995).

Job satisfaction is the general attitude of an individual to his job. Job satisfaction rises through a series of evaluation processes carried out by employees. Job satisfaction is one of the most decisive variables in the organizational behavior model (Robbins, 2006). If the existing conditions are greater than the conditions that should be there, then the employee will feel satisfied, on the contrary, if the condition that should be greater is felt than the existing conditions, then the employee will feel dissatisfied. Moreover, Robbins (2006) explains that high job satisfaction means a lot to employees and organizations. Low job satisfaction can cause employees to choose to work in a place that is 
considered more able to provide satisfaction. Therefore, this condition must be a concern of the management in managing its employees.

Gibson (2003) describes there is a reciprocal relationship between performance and satisfaction. Job satisfaction of nurses is one of the most important things in the hospital industry because employee attitudes and behavior are related to the quality of service. Customer satisfaction and perception of the quality of hospital services is influenced by the attitudes and behavior of services provided by employees, especially nurses. An increase performance and job satisfaction can only be achieved if good communication exists in the organization, especially interpersonal communication. Interpersonal communication is the transfer of information from one person or from a group of others. Good communication will improve the professional relationship between nurses and other health teams, in providing information and clarity from each individual in accordance with his position. Communication as an exchange of thoughts, feelings and opinions, gives advice that occurs between one or more people who work together. Communication is effective if the recipient interprets the message received as intended by the sender of the message. Interpersonal communication is very important for human survival. Interpersonal communication will facilitate mutual understanding among the people involved in communication and then develop a relationship that is satisfying for both parties and effective cooperation.

Therefore, this study aimed to: (1) analyze the effect of interpersonal communication on nurses' job satisfaction in health care centers in Makassar (2) analyze the effect of interpersonal communication on nurses' performance in health care centers in Makassar, (3) To analyze the effect of job satisfaction on nurses' performance in health care centers in Makassar, (4) to analyze the influence of in direct interpersonal communication on nurse performance through job satisfaction of nurses in health care centers in Makassar.

\section{Research Methodology}

This research was conducted in Makassar City with a unit of analysis of nurses at the health care centers in Makassar. This research is an associative research, that aimed to determine the relationship between two or more variables (Sugiyono, 2012). Data collection was conducted with survey methods using questionnaires that can include all information related to interpersonal communication, job satisfaction, and performance of nurses in health care centers in Makassar. The responses applied 5likert scale. The population in this study was all nurses at the Puskesmas in the city of Makassar, which numbered 405 people. The sampling technique was carried out in two stages, namely the first stage of choosing an inpatient health center as many as 10 health centers with a total of 130 nurses. The second stage determines the nurse sample using the Slovin formula: $n=N /\left(1+\mathrm{Ne}^{2}\right)$. $n$ is the sample size, $\mathrm{N}$ is the population, and e is the percentage of tolerated accuracy allowance (5\%). Therefore, the minimum sample size was 98 nurses. The sampling procedure applied a non probability sampling with a proportional random sampling method to determine a proportional sample.

The highest number of respondents in this study were 71 women $(72.45 \%)$ compared to 27 men $(27.55 \%)$. Based on age, it is dominated by the age range of 25-30 years as many as 52 people $(53.06 \%)$, age range $\geq 30$ years as many as 21 people $(21.43 \%)$, age range $20-25$ years as many as 19 people $(19.39 \%)$ and finally in the age range $\leq 20$ years as many as 6 people $(6,12 \%)$. Characteristics of respondents based on status are: unmarried status of 66 people $(67.35 \%)$ and married respondents as many as 32 people (32.65\%). Respondents based on years of work, respondents who were the most were 5-10 years working period as many as 34 people (34.69\%), respondents with a working period of 2-5 years as many as 26 people $(26.53 \%)$, respondents with tenure of $1-2$ years with the number of respondents as many as 21 people $(21.43 \%)$, and respondents with the least working period, namely $\geq 10$ years as many as 17 people (17.35\%). This concludes that the inpatient Puskesmas employees have an average working period of 1-2 years. Respondents based on the latest education were dominated by nurses with the latest education, namely university level / equivalent to a total of 84 
people $(85.71 \%)$ and the rest were respondents with the latest education level namely D1 / D3 or equivalent $(14.29 \%)$.

\section{Result and Discussion}

This study applied: (1) descriptive qualitative analysis; This method is used to describe or illustrate the characteristics of respondents, which include the description of age, education, length of time and various other characteristics, (2) quantitative analysis using path analysis to find out how much influence the independent variable (interpersonal communication) has on the dependent variable (job satisfaction and performance of nurses) both directly and indirectly. The process was carried out with the help of SPSS software.

Description of Research Variables. The results of respondents' responses are as follows. The respondent's assessment of interpersonal communication was the average of 3.68 and this was in the good and high category. The indicator with the highest contribution is the physiological indicator with an average value of 3.86. Regarding the openness indicators, many respondents felt that they were leaders regarding openness in line with respondents' expectations. Other indicators of safety influence and safety contained with average scores of 3.70. Related to indicators, each health center implements mutual support among nurses. Furthermore, the last indicator that also gives good influence in terms of interpersonal communication is an average value of 3.64.

For respondents' assessment of the research variables on job satisfaction shows that the average variable job satisfaction is at a value of 3.59 where it can be said that Nurse's job satisfaction in Makassar is in a fairly high position or in the good category. Job satisfaction is assessed from 4 indicators of assessment which are then outlined in several statements. The results of the indicator of opportunity for promotion has the highest value, which is 3.66, followed by indicators of factors of coworkers with an average value of 3.55, then financial factors with an average value of 3.54 and the last monitoring factor with an average value of 3.45 .

For performance variables, which consist of several statements that are considered for presenting the variable's indicators. The results of the responses were the average performance variable was 3.75 which could be categorized as a good condition and was in a high enough position. The indicators with the highest contribution are the quantity of work and initiatives that are equal at an average value of 3.79. Another indicator is personal quality, has a fairly high average value of 3.77. And the last is the indicator of creativity has an average value of 3.71 .

Test of Validity and Reliability of Variables. Validity test shows the extent to which a measuring device measures what is measured. The validity test, each value in $r$ count is compared with the value of $r$ in the table $r$ with a free degree $n-2$ where $n$ is the number of respondents that is 98 so that the value used in this case is table $r$ with 96 free degrees and 0.198 . The indicator or questionnaire used by each interpersonal communication variable, job satisfaction and performance is declared valid to be used as a measurement tool, because it has a correlation value above 0.30 .

Reliability tests show that the instrument is believed to be used as a data collection tool. Reliability is measured by the cronbach's alpha $(\alpha)$ statistical test by comparing the Alpha value with the standard, the reliability of a variable construct is said to be good if it has a Cronbach's Alpha value of $\geq 0.6$, which means that the reliability level of 0.6 is a reliable indication (Sugiono, 201). The results of the calculation of alpha coefficient of each variable are: Cronbach's alpha values for interpersonal communication, job satisfaction and performance are $\geq 0.6$, Therefore, that indicators or questionnaires are valid.

Regression Test for Substructure 1. Interpersonal Communication to Job Satisfaction are as follows: 
Table 1. Determination Test for Interpersonal Communication to Job Satisfaction (Model Summary)

\begin{tabular}{|c|c|c|c|c|}
\hline Model & $\mathrm{R}$ & $\mathrm{R}$ Square & $\begin{array}{c}\text { Adjusted } \\
\text { R Square }\end{array}$ & $\begin{array}{c}\text { Std Error of the } \\
\text { Estimate }\end{array}$ \\
\hline 1 & $640 \mathrm{a}$ & 0.41 & 0.404 & 3.66424 \\
\hline
\end{tabular}

a. Predictors: (Constant), Interpersonal Communication

Simultaneously, interpersonal communication variables (X) have a contribution of $41 \%$ in explaining the changes that occur in the variable job satisfaction (Y1) while the remaining $59 \%$ is explained by other variables outside the model.

Table 2. F Test Results (ANOVA $\left.{ }^{a}\right)$

\begin{tabular}{|c|c|c|c|c|c|}
\hline Model & $\begin{array}{l}\text { Sum of } \\
\text { Squares }\end{array}$ & & $\begin{array}{l}\text { Mean } \\
\text { Square }\end{array}$ & $\mathrm{F}$ & Sig. \\
\hline Regression & 894.431 & 1 & 894.431 & 66.616 & $.000^{\mathrm{b}}$ \\
\hline Residual & 1288.956 & 96 & 13.427 & & \\
\hline Total & 2183.388 & 97 & & & \\
\hline
\end{tabular}

a. Dependent Variable: Job Satisfaction

b. Predictors: (Constant), Interpersonal Communication

The results show Sig. in the ANOVA table the Sig. is equal to 0,000 or smaller than the probability value of 0.05 ( $\operatorname{sig} 0,000<0.050$ ), then Ho is rejected and $\mathrm{Ha}$ is accepted. This means that multiple regression coefficients are significant. So that interpersonal communication variables (X) have a simultaneous and significant effect on job satisfaction (Y1).

Table 3. T Test Results (Coefficients ${ }^{\mathrm{a}}$ )

\begin{tabular}{|c|c|c|c|c|c|}
\hline \multirow[b]{2}{*}{ Model } & \multicolumn{2}{|c|}{$\begin{array}{l}\text { Unstandardized } \\
\text { Coefficients }\end{array}$} & $\begin{array}{l}\text { Standardized } \\
\text { Coefficients }\end{array}$ & \multirow[b]{2}{*}{$\mathrm{T}$} & \multirow[b]{2}{*}{ Sig. } \\
\hline & B & Std. Error & Beta & & \\
\hline (Constant) & 11.946 & 3.072 & & 3.889 & 0 \\
\hline $\begin{array}{l}\text { Interpersonal } \\
\text { Communication }\end{array}$ & 0.694 & 0.085 & 0.64 & 8.162 & 0 \\
\hline
\end{tabular}

a. Dependent Variable: Job satisfaction

The $t$ test or partial test shows that the interpersonal communication variable (X) has a positive influence shown by standard beta coefficient $(0.640)$ and has a significant effect on the job satisfaction variable (Y1) indicated by the Sig value is smaller than Alpha 5\%.

Test Results for Regresi Substructure 2. 
Table 4. Determination Test for Interpersonal Communication and Job Satisfaction to Performance (Model Summary)

\begin{tabular}{|c|l|r|l|l|}
\hline Model & $\mathrm{R}$ & $\mathrm{R}$ Square & Adjusted $\mathrm{R}$ & Std. Error of the \\
\hline 1 & & 0.778 & 0.774 & \\
\hline
\end{tabular}

a. Predictors: (Constant), Job Satisfaction, Interpersonal Communication

Simultaneously, the variables of interpersonal communication (X) and job satisfaction (Y1) have a contribution of $77.8 \%$ in explaining the changes that occur in the nurse performance variable (Y2) while the remaining $22.2 \%$ is explained by other variables outside the model.

Tabel 5. F Test Results (ANOVA $\left.{ }^{\mathrm{a}}\right)$

\begin{tabular}{|l|r|r|r|r|r|}
\hline \multirow{2}{*}{ Model } & $\begin{array}{r}\text { Sum of } \\
\text { Squares }\end{array}$ & df & Mean Square & F & Sig. \\
\hline Regression & 1410.959 & 2 & 705.479 & 166.925 & \\
\cline { 2 - 6 } Residual & 401.5 & 95 & 4.226 & & \\
\cline { 2 - 6 } Total & 812.459 & 97 & & & \\
\hline
\end{tabular}

a. Dependent Variable: Performance

b. Predictors: (Constant), Job Satisfaction, Interpersonal Communication

The results of the Sig analysis in the ANOVA table the Sig. is equal to 0,000 or smaller than the probability value of 0.05 ( $\operatorname{sig} 0,000<0.050$ ), then Ho is rejected and Ha is accepted. This means that multiple regression coefficients are significant. Therefore, the variables of interpersonal communication (X) and job satisfaction (Y1) influence simultaneously and significantly on nurse performance (Y2).

Table 6. T Test Results (Coefficients ${ }^{\mathrm{a}}$ )

\begin{tabular}{|l|c|c|c|c|c|}
\hline \multirow{2}{*}{ Model } & \multicolumn{2}{|c|}{$\begin{array}{c}\text { Unstandardized } \\
\text { Coefficient }\end{array}$} & $\begin{array}{c}\text { Standardized } \\
\text { Coefficients }\end{array}$ & \multirow{2}{*}{$\mathrm{T}$} & Sig. \\
\cline { 2 - 5 } (Constant) & $\begin{array}{c}\mathrm{B} \\
4.516\end{array}$ & $\begin{array}{c}\text { Std.Error } \\
1.854\end{array}$ & Beta & 2.435 & 017 \\
\hline $\begin{array}{l}\text { Interpersonal } \\
\text { Communication }\end{array}$ & 0.332 & 0.062 & 0.336 & 5.348 & 0 \\
\hline Job Satisfaction & 0.573 & 0.057 & 0.629 & 10.001 & 0 \\
\hline
\end{tabular}

a. Dependent Variable: Performance 
The $t$ test coefficient or partial test shows that the variables of interpersonal communication $(\mathrm{X})$ and job satisfaction (Y1) statistically have a positive and significant effect on the nurse performance variable (Y2) indicated by the Sig value is smaller than Alpha 5\%.

Table 7. Results of Path Regression Analysis

\begin{tabular}{|l|r|r|r|l|l|}
\hline Variabel & $\begin{array}{c}\text { Direct } \\
\text { influence }\end{array}$ & $\begin{array}{c}\text { Indirect } \\
\text { influence }\end{array}$ & $\begin{array}{c}\text { Total } \\
\text { Influence }\end{array}$ & $\mathrm{T}$ test & remarks \\
\hline $\mathrm{X}-\mathrm{Y} 1$ & 0.640 & - & 0.640 & 8.162 & significant \\
\hline $\mathrm{X}-\mathrm{Y} 2$ & 0.336 & - & 0.336 & 5.348 & significant \\
\hline $\mathrm{Y}-\mathrm{Y} 2$ & 0.629 & - & 0.629 & 10.001 & significant \\
\hline $\mathrm{X}-\mathrm{Y} 1-\mathrm{Y} 2$ & & 0.402 & 0.738 & 5.348 & significant \\
\hline
\end{tabular}

The results of the analysis show that the total direct effect of interpersonal communication on job satisfaction is obtained by regression coefficient of 0.640 which can be categorized as having a high enough influence. Furthermore, the direct influence of interpersonal communication variables on nurse performance with a regression coefficient of 0.336 . This shows that there are still many other influences outside of interpersonal communication that can provide a better influence on the performance of a nurse.

The results above also show the effect of job satisfaction on nurse performance with a regression coefficient of 0.629 . This shows that someone is satisfied with a job so it will increasingly influence the performance of the nurse. The results of the calculation above also show that the total direct effect obtained by the regression coefficient value of interpersonal communication in nurse performance is 0.336 , while the total indirect effect is 0.402 , when compared then the total direct effect $<$ total indirect effect $(0.336<0.402)$. Because the indirect influence is greater than the direct effect, it can be concluded that job satisfaction can be a mediating variable between interpersonal communication in nurse performance.

\section{Conclusion}

Based on the results of research, this study provides several the conclusions in this study are as follows:

1) Interpersonal communication has a positive and significant effect on the job satisfaction of Inpatient Health Center Nurses in Makassar

2) Interpersonal Communication has a positive and significant effect on the performance of Inpatient Health Center Nurses in Makassar

3) Job satisfaction has a positive and significant effect on the performance of Inpatient Health Center Nurses in Makassar

4) Interpersonal Communication has a positive and significant indirect effect on performance through the job satisfaction of Inpatient Health Center Nurses in Makassar.

This study proposed several suggestions as follows:

1) Nurses in health centers in Makassar need to improve the application of interpersonal communication between superiors and subordinates and among fellow employees because in addition to influencing job satisfaction can also improve nurse performance in a direction that is further enhanced in better conditions.

2) Nurses at Puskesmas need to consider nurses 'job satisfaction so that nurses' performance can be maintained and further improved in better conditions.

3) To improve job satisfaction employees need attention in terms of company management and adequate office facilities so that employees can work optimally and can improve performance in accordance with what is expected by the Puskesmas. 
4) For further researchers, studies should be conducted by deepening or developing research variables, so that other findings can be obtained for the development of science.

\section{References}

Anwar Prabu. 2004. Manajemen Sumber Daya Manusia. Ramaja Rosda Karya. Bandung.

Barney, J.B. \& Griffin, R.W., 1992. Management of Organizations: Strategy, Structure and Behavior.

Houghton Mifflin Company. Boston.

Cascio,W.F, 1995. Managing Human Resources: Productivity, Quality of Work Life, Profits. Third

Edition, McGraw Hill Inc., New York.

Departemen Kesehatan RI, 1991, Pedoman Kerja Puskesmas jilid IV Jakarta.

Departemen Kesehatan RI, 1993, Perawatan Kesehatan Masyarakat Jakarta

Gibson, James. L., John. M. Ivancevich, and James. H. Donnely. 1997. Organisasi dan Manajemen:

Perilaku, Struktur dan Proses. Jilid 1. Edisi Kelima. Terjemahan. Penerbit Erlangga. Jakarta. , 2003. Organisasi Perilaku, Struktur, Proses. Bina Rupa Aksara. Jakarta.

Gomes, Foustino Cordoso, 2000. Manajemen Sumber Daya Manusia. Cetakan Kedua. Andi Offset. Yogyakarta.

Luthans, Fred. 2006. Organizational Behavior $8^{\text {th }}$ ed. McGraw-Hill International Edition. Singapore.

Mangkunegara, $\quad$ Anwar P. 2000. Manajemen Sumber Daya Manusia. Edisi Keempat. Gajah Mada University Press. Yogyakarta.

Notoatmojo dan Soekidjo, 1992. Pengembangan Sumber Daya Manusia. Cetakan Pertama. Penerbit Rineka Cipta. Jakarta.

Robbins, P, Stephen, P., 2006. Perilaku Organisasi. Edisi Kesepuluh. Alih Bahasa oleh Drs. Benyamin Molan. PT. indeks. Jakarta.

Schermerhorn, J.R., Jr., Hunt, J.G. and Osborn, R.N. 1998. Basic Organizational Behavior. $2^{\text {nd }}$ ed. John. Wiley. New York.

Sitorus, 2000. Model Praktek Keperawatan Sebagai Upaya Peningkatan Dalam Pelayanan Keperawatan, Munas PPNI, Bandung.

Smith, N. Coley, B. \& White, J.K. 1969. Back Ground, Need, Job Perceptions and Job Satisfaction, Journal of personnel Psychology, Vol. ed. John. Wiley. New York.

Sugiyono. 2012. Metode Penelitian Kuantitatif Kualitatif dan R\&D. Bandung: Alfabeta , 1969. Back Ground, Need, Job Perceptions and Job Satisfaction, Journal of personnel Psychology, Vol. 31., No. 4. 889-901.

Vecchio, R.P., 2000. Organizational Behavior, Core Concept. Fourth Edition.Harcourt College Publisher. Orlando USA.

Winardi, J. 2004. Manajemen Perilaku Organisasi. Prenada Media. Bandung.

Zin, Razali Mat. 2004. Perception of Professional Engineers Toward Quality of Work Life and Organizational Commitment., Gajahmada International Journal of Business, Vol. 6. No. 3, p.323-334. 